\begin{tabular}{l} 
SCIENCE \& TECHNOLOGY \\
Journal homepage: http://www.pertanika.upm.edu.my/ \\
\hline PERTANIKA
\end{tabular}

\title{
Traffic Noise Level Assessment in the Residential Area around Different Road Functions in Malang City, East Java, Indonesia
}

\author{
Ngudi Tjahjono ${ }^{1}$, Imam Hanafi ${ }^{2}$, Latipun Latipun ${ }^{3}$ and Suyadi Suyadi** \\ ${ }^{\prime}$ Department of Industrial Engineering, Faculty of Engineering, University of Widyagama Malang, Malang, \\ East Java, Indonesia \\ ${ }^{2}$ Faculty of Administrative Sciences, University of Brawijaya, Malang, East Java, Indonesia \\ ${ }^{3}$ Faculty of Psychology, University of Muhammadiyah Malang, Malang, East Java, Indonesia \\ ${ }^{4}$ Faculty of Animal Sciences, University of Brawijaya, Malang, East Java, Indonesia
}

\begin{abstract}
Noise due to motorized vehicles is a major problem in urban areas which can interfere with physiological and psychological health. This study aims to determine the extent of noise levels outside and inside the house around the function of different roads in Malang City, East Java, Indonesia. The study was conducted by measuring the traffic noise level using a sound level meter. Measurements were taken in the afternoon between 16.00-21.00 during the peak of heavy traffic and outside working hours when residents were already at home. Statistical Student's t-test analysis was used to test differences in the average noise level outside and inside the house on each road function. Variance analysis was used to compare noise levels around primary arterial roads, secondary arteries, primary collectors, secondary collectors, primary local, and secondary local. From the measurement results, it is known that the noise due to motorized vehicles is $84.28 \mathrm{~dB}$ on average. This exceeds the threshold based on the Decree of the State Minister for the Environment Number 48 of 1996. There was a significant difference in noise level between outside and inside the house on each road function. There was no

ARTICLE INFO

Article history:

Received: 03 November 2020

Accepted: 10 February 2021

Published: 31 July 2021

DOI: https://doi.org/10.47836/pjst.29.3.05

E-mail addresses:

ngudi.widyagama@gmail.com (Ngudi Tjahjono)

imamhanafi@ub.ac.id (Imam Hanafi)

latipun@umm.ac.id (Latipun Latipun)

suyadi@ub.ac.id (Suyadi Suyadi)

* Corresponding author significant difference in noise level between the functions of the road segments both outside and inside the house. The results of the study concluded that the traffic noise level at 16:00 to 21:00 hours on all roads that were targeted for research exceeds the national threshold. It is recommended that the level of traffic noise around roads in
\end{abstract}


the city of Malang can be reduced to minimize the negative impact on physiological and psychological health.

Keywords: National threshold, noise level, road function, traffic noise

\section{INTRODUCTION}

The increase in the number of motorized vehicles causes many problems in urban areas. This is faced by many big cities in the world. This increase is in line with the increasingly complex human needs that require the support of transportation facilities in the form of motorized vehicles. However, in several big cities in Indonesia the rapid increase in the number of motorized vehicles has not been matched by an increase in the capacity of adequate road infrastructure (Ningsih, 2010). This has become one of the causes of environmental degradation.

Facts obtained from several studies show that the big cities in the world cannot be separated from traffic noise. In cities in India, traffic noise caused by heavy traffic flow conditions in the main corridor Bus Rapid Transport System (BRTS) has exceeded the national standards of the Central Pollution Control Board (CPCB) (Mishra et al., 2010). Likewise in Tehran, most of the business centers and settlements around the main roads are exposed to noise pollution (Alesheikh \& Omidvari, 2010).

Research in Bandung shows that the average noise level on all major roads have exceeded the specified quality standards (Pryandana, 2000). On several local roads in Bandung also showed the same condition (Setiawan et al., 2016; Wahyuni et al., 2019). The same results were shown in a study in Manado (Balirante et al., 2020), Meulaboh (Kurnia et al., 2018) and Padang (Putra \& Lisha, 2017).

The level of traffic noise that exceeds the threshold of the Decree of the Minister of Environment No. 48 of 1996 can disturb people who are exposed both physiologically and psychologically. There are two stages in the decline in mental health level as a result of poor environmental quality including due to noise factors, namely (a) will directly affect behavior, attitudes and utilization of health services, and (b) long-term related with the accumulation of stress and limited environmental resources (Halim, 2008). Meanwhile, research in primary schools shows that students exposed to traffic noise $>61.8$ dBALeq in a school environment have a 10.9 times risk of experiencing psychological health problems (Djaja \& Wulandari, 2007), the same thing was also studied at SMPN 3 Kendari (Ibnu, 2019). The accuracy of hearing also decreased (Yadnya et al., 2009). Also found the fact that there is a relationship between noise and hypertension suffered by women who live around the railroad tracks (Rosidah, 2004).

From the revealed facts, it is necessary to do further research on the noise level from motorized vehicle sources in Malang City. The purpose of this study was to determine the 
extent of noise levels outside and inside the house around the function of different roads in Malang, East Java, Indonesia.

\section{MATERIALS AND METHOD}

\section{Research Location}

The research location is in the city of Malang, East Java province, Indonesia (Figure 1). Malang City is the second largest city in East Java after Surabaya. Geographically, the city of Malang is located at position $112^{\circ} 38^{\prime} 01.7^{\prime \prime}$ East Longitude and $7^{0} 58^{\prime} 42.2^{\prime \prime}$ South Latitude covers an area of $11,006 \mathrm{Km}^{2}$.

Malang City is located in the middle of Malang Regency administration area. North side, bordering Singosari District and Karangploso District Malang Regency. In the south, it is bordered by Tajinan subdistrict and Pakisaji subdistrict, Malang regency. West side, bordering Wagir District Malang Regency and Dau District Malang Regency. East side, bordering Pakis District and Tumpang District, Malang Regency.

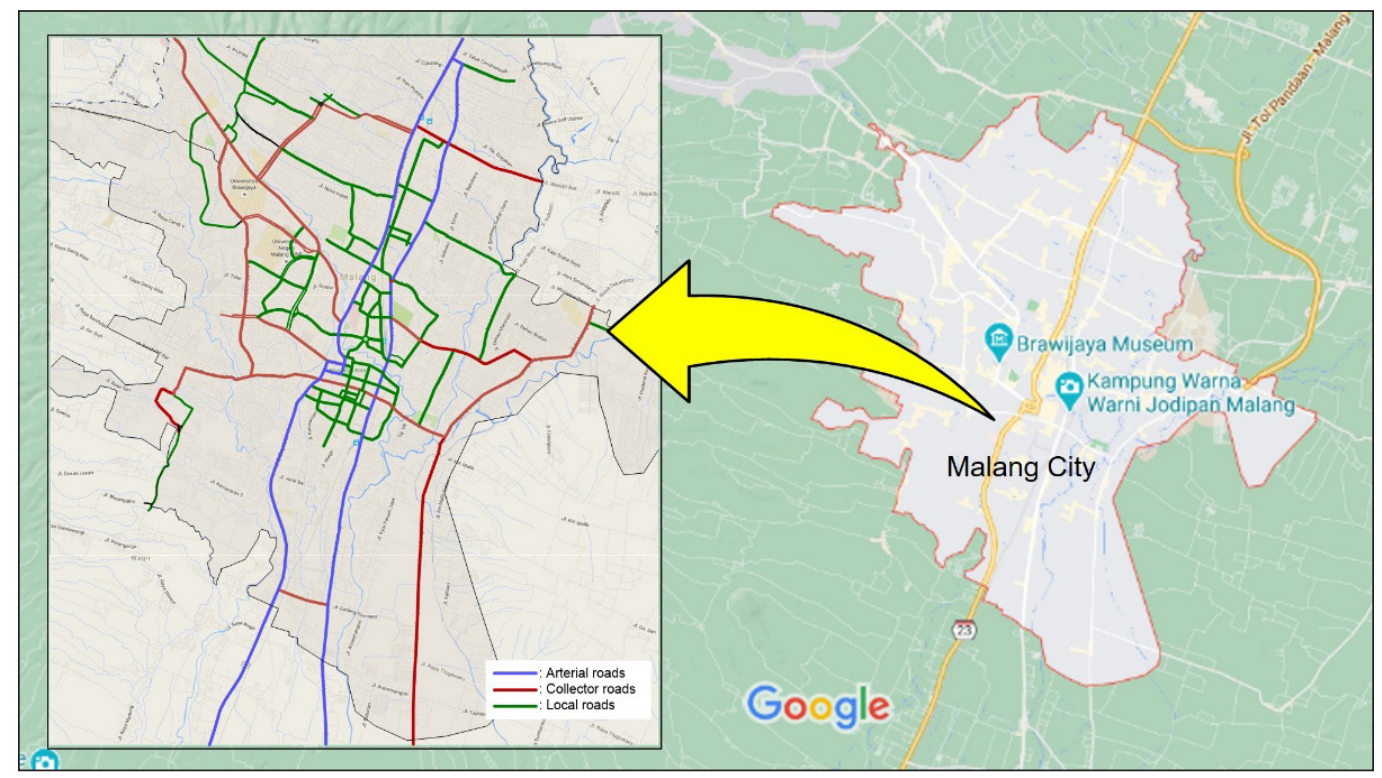

Figure 1. The research location on the arterial, collector, and local roads in the city of Malang

\section{Types of Roads}

Judging from the function of the roads contained in the city of Malang can be divided into: Primary Arterial roads, Secondary Arteries, Primary Collectors, Secondary Collectors, Primary Local, Secondary Local. In terms of existing road patterns, the Malang City road transportation pattern is a radial concentric pattern with an inner ring system of the local road network that forms a grid pattern. The total length of the road based on the function 
is $663.34 \mathrm{~km}$. The details of the length of the road network in Malang based on the road function are described in Table 1.

\section{Research Methods}

The population of the road is the entire road network in the city of Malang. Determination of the sample of road segments is done by selecting the road segments that represent the functions of primary arterial roads, secondary arteries, primary collectors, secondary collectors, primary local and secondary local. The selection of road segments is based on the consideration that in addition to representing the function of the road, there are also many houses that are not used as business premises around the road segments. This consideration was taken because the focus was to find out the condition of motorized traffic noise that exposed the population living in the vicinity. Based on the above criteria, a sample of 41 road sections are spread across 6 road functions.

Noise measurement points are set at least in three places, namely the base, middle and end of each road section. The determination of the three points is expected to be able to represent the character of the flow of motorized vehicles passing along the road.

\section{Data Types and Collection}

The data was measured in the form of the distance from the house to the road axis and noise data generated from the road outside and inside the house. Noise level was measured using a Sound Level Meter. The measuring instrument used is the 4 IN 1 Multi-functional Environmental Meter. This tool is capable of measuring noise in the range of Lo $=30-100$ $\mathrm{dB} ; \mathrm{Hi}=65-130 \mathrm{~dB}$.

Data collection points were determined at least at the end, middle and end of the road section. Data was measured based on the ear height of a person sitting in a chair with consideration at rest, many people do it while sitting. Data collection was carried out in the afternoon until evening with the consideration that the residents were already at home. Noise measurements were carried out on terraces and inside residents' houses with a duration of about five minutes. The data recorded was the average noise data over the measurement duration.

\section{Data Analysis}

The data collected is carried out reduction and compilation to make an assessment according to the category. Data were analyzed with descriptive statistical tools and analysis of 
variance. Descriptive analysis is needed to describe the distribution of the distance of the house to the street. While analysis of variance is needed to determine differences in noise levels on each road function.

The description of the data is presented in statistical Table 2 and Figure 2 as a representation of the collected data. Table 2 contains frequency and percentage information on the distance of the house to the ace of the road. While the graph is presented in the form of three-dimensional blocks.

The difference in noise levels between outside and inside the house on each road function is calculated by the Student's t unpaired test. One-way analysis of variance (ANOVA) was calculated using Excel, to see differences in noise levels between each group of road functions.

After that proceed with making a map of Malang city traffic noise in the form of a two-dimensional map for the road sections included in the study.

\section{RESULT}

Measurement of motor vehicle noise is carried out on samples of road segments that represent the functions of primary arterial roads, secondary arteries, primary collectors, secondary collectors, primary local and secondary local. The selection of road sections is based on the consideration that in addition to representing the function of the road as well as around these roads there are residents' houses that are not used as places of business.

\section{Distance From House to the Ace of the Street}

From the data collected, it was found that most of the houses have a distance from the axle of the road between 5.1 and 10 meters. Of course, such distance is too close to the source of the noise on the road. Furthermore, it can be seen in Table 2 and Figure 2.

From the measurement, information was obtained that the existence of a house on the side of the road is too close to the road. Examples of cases like this can be seen in Figure 3 which was taken from Google Maps and Figure 4 which was taken directly at

Tabel 2

Amount and percentage of distribution of distances from houses to the axle of the road

\begin{tabular}{clrr}
\hline No & Distance from Road & Frequency & Percentage $(\%)$ \\
\hline 1 & $\leq 5$ meters & 7 & 4.52 \\
2 & $5,1-10$ meters & 128 & 82.58 \\
3 & $10,1-15$ meters & 18 & 11.61 \\
4 & $15,1-20$ meters & 1 & 0.65 \\
5 & $\geq 20,1$ meters & 1 & 0.65 \\
\hline & Total & 155 & 100.00 \\
\hline
\end{tabular}

Source: Primary Data Processed 


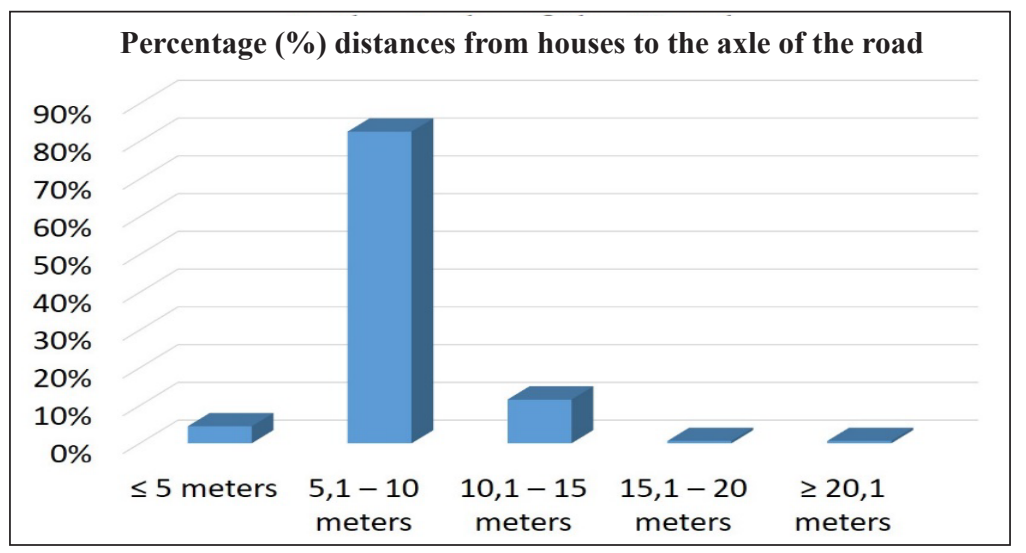

Figure 2. Percentage (\%) distances from houses to the axle of the road

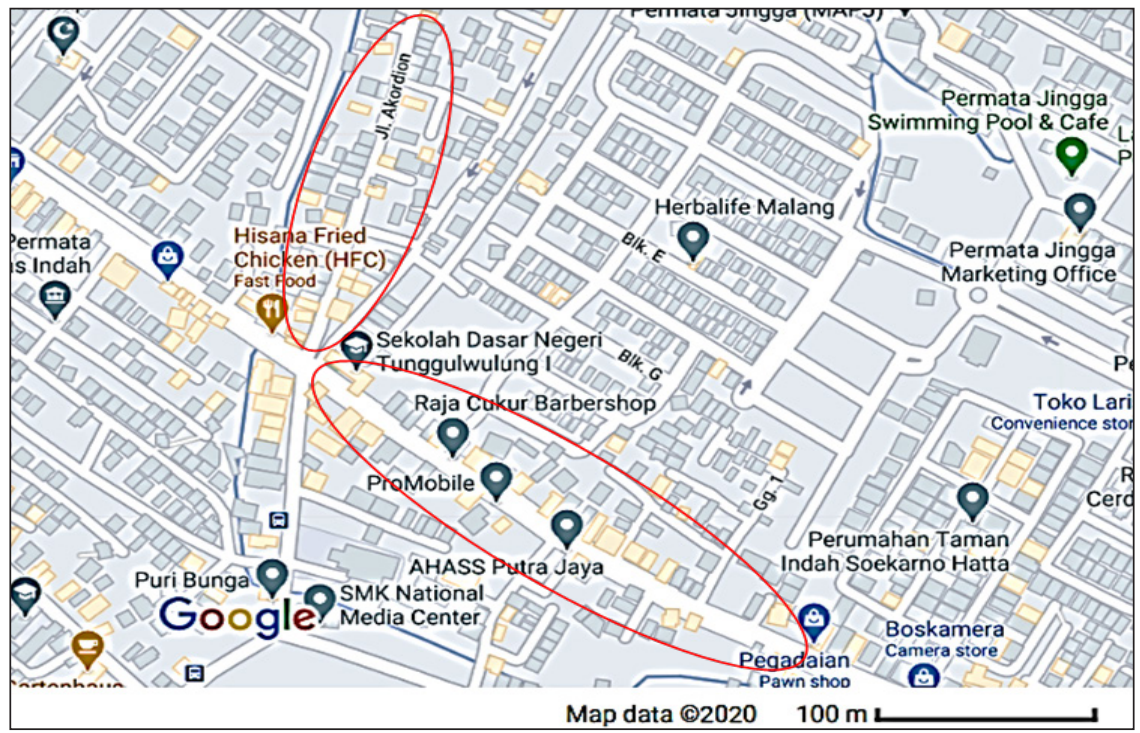

Figure 3. An example of the location of a house that is too close to the road. The houses marked with an oval line are located on Candi Panggung and Akordion streets, Malang city.

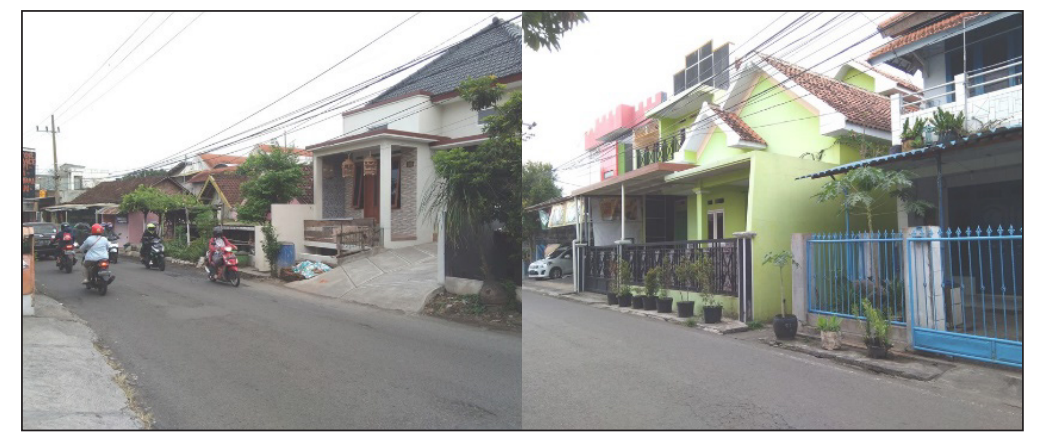

Figure 4. An example of the images of the houses that were too close to the road, which was taken directly on Akordion streets, Malang city. 
the location. A distance that is too close like this has the potential for high levels of noise to which it is exposed.

\section{Analysis of the Mean Noise Level outside and inside the House}

Based on research data obtained from measurement, data showed on the mean noise level outside and inside the house for each of the functions can be seen in Table 3. The standard deviation is calculated from the data collected can also be seen in Table 3 .

To find out the difference in the mean noise level outside and inside the house for each road function, it was carried out using the unpaired Student's t test. The results can be seen in Table 4.

From the analysis of Student's t-test there was a significant difference at $t_{0.05}$. A significant difference in mean of noise level between outside and inside the house occurs in each function of the road section. These differences show that the noise level outside the house can be significantly reduced inside the house. This is caused by the various kinds of efforts made by residents to reduce noise from motor vehicles on the road.

Some efforts to reduce the noise that is commonly found in houses scattered around roads in the city of Malang, among others, close their homes tightly. Doors and windows

Table 3

Noise level $(\bar{x} \pm s)$ outside and inside the house for each road function

\begin{tabular}{cllcc}
\hline No & Road Function & & Outside the House & Inside the House \\
\hline 1 & Primary Artery & Number of roads, $\mathrm{n}$ & 4 & 4 \\
& & Mean of noise level, $\bar{x}$ & 84.55 & $70.10^{*}$ \\
& & Standard deviation, $\mathrm{s}$ & 1.85 & 6.09 \\
\hline 2 & Secondary Artery & Number of roads, $\mathrm{n}$ & 4 & 4 \\
& & Mean of noise level, $\bar{x}$ & 85.13 & $69.40^{*}$ \\
& & Standard deviation, $\mathrm{s}$ & 1.79 & 3.89 \\
\hline 3 & Primary Collector & Number of roads, $\mathrm{n}$ & 2 & 2 \\
& & Mean of noise level, $\bar{x}$ & 83.20 & $67.15^{*}$ \\
& & Standard deviation, $\mathrm{s}$ & 0.57 & 2.62 \\
\hline 4 & Secondary Collector & Number of roads, $\mathrm{n}$ & 13 & 13 \\
& & Mean of noise level, $\bar{x}$ & 84.50 & $69.30^{*}$ \\
& & Standard deviation, $\mathrm{s}$ & 2.68 & 4,00 \\
\hline 5 & Primary Local & Number of roads, $\mathrm{n}$ & 2 & 2 \\
& & Mean of noise level, $\bar{x}$ & 83.15 & $68.90^{*}$ \\
& & Standard deviation, $\mathrm{s}$ & 0.92 & 1.13 \\
\hline 6 & Secondary Local & Number of roads, $\mathrm{n}$ & 16 & 16 \\
& & Mean of noise level, $\bar{x}$ & 84.09 & $66.71^{*}$ \\
& & Standard deviation, $\mathrm{s}$ & 3.40 & 9.15 \\
\hline
\end{tabular}

Source: Primary data processed

Note: $*$ there is a significant difference in $\mathrm{t}_{0,05}$ 
Table 4

Result of T test calculation

\begin{tabular}{cllll}
\hline No & Road Fungtion & $\mathrm{t}_{\text {count }}$ & $\mathrm{t}_{0.05}$ & Conclusion \\
\hline 1 & Primary Artery & 4.541 & 1.943 & Significant \\
2 & Secondary Artery & 7.347 & 1.943 & Significant \\
3 & Primary Collector & 8.465 & 2.920 & Significant \\
4 & Secondary Collector & 11.382 & 1.711 & Significant \\
5 & Primary Local & 13.830 & 2.920 & Significant \\
6 & Secondary Local & 7.122 & 1.645 & Significant \\
\hline
\end{tabular}

Source: Primary data processed

are made tight and even air vents are also closed to reduce noise and prevent dust from entering the room. The curtains that are used to protect the room from the eyes of people outside the house also function as a silencer. Ornamental plants planted on the fence of the house or the terrace of the house can also reduce the intensity of noise from the road. Research has been conducted on various types of plants that can reduce noise in Malang (Tjahjono \& Nugroho, 2018) and Sidoarjo (Pudjowati et al., 2013). From both studies, it is known that plant species can effectively reduce noise.

\section{Analysis of Variance of Noise Level on Each Function of Roads}

Data collected includes road segments grouped into road functions, the mean noise level in each section presented in Tables 5 and 6.

By using analysis of variance, it can be concluded that there is no significant difference between the functions of road segments (primary arteries, secondary arteries, primary collectors, secondary collectors, primarily local and secondary local) for average noise levels outside the house or inside the house. This shows that the noise level originating from motorized vehicles in the streets of Malang has exceeded the required noise level. Even though the noise inside the house can be muted, it is still above the threshold or greater than $55 \mathrm{~dB}$.

Table 5

Variance analysis for average noise level outside the house

\begin{tabular}{|c|c|c|c|c|c|c|}
\hline \multirow{2}{*}{ Source } & \multirow{2}{*}{$\mathrm{df}$} & \multirow{2}{*}{ SS } & \multirow{2}{*}{ MS } & \multirow{2}{*}{$F_{\text {count }}$} & \multicolumn{2}{|c|}{$\mathrm{F}_{\text {table }}$} \\
\hline & & & & & $5 \%$ & $1 \%$ \\
\hline Treatment & 5 & 9.26 & 1.85 & 0.23 & 2.49 & 3.60 \\
\hline Error & 35 & 280.56 & 8.02 & & & \\
\hline Total & 40 & 289.82 & & & & \\
\hline
\end{tabular}

Source: Primary data processed

Because $\mathrm{F}_{\text {count }}=0.23$ is smaller than $\mathrm{F}_{\text {table }}$ at the level of $1 \%=3.60$, so it can be concluded that there is no difference in noise levels in each treatment group (road function) 
Table 6

Variance analysis for average noise level inside the house

\begin{tabular}{|c|c|c|c|c|c|c|}
\hline \multirow{2}{*}{ Source } & \multirow{2}{*}{$\mathrm{df}$} & \multirow{2}{*}{ SS } & \multirow{2}{*}{ MS } & \multirow{2}{*}{$\mathrm{F}_{\text {count }}$} & \multicolumn{2}{|c|}{$F_{\text {table }}$} \\
\hline & & & & & $5 \%$ & $1 \%$ \\
\hline Treatment & 5 & 74.58 & 14.92 & 0.32 & 2.49 & 3.60 \\
\hline Error & 35 & 1611.93 & 46.06 & & & \\
\hline Total & 40 & 1686.52 & & & & \\
\hline
\end{tabular}

Source: Primary data processed

Because $\mathrm{F}_{\text {count }}=0.32$ is smaller than $\mathrm{F}_{\text {table }}$ at the level of $1 \%=3.60$, so it can be concluded that there is no difference in noise levels in each treatment group (road function).

\section{Motor Vehicle Noise Level Mapping in the City of Malang}

From the noise measurement data collected then plotted to the Malang City road map which is downloaded from the Google Map. Roads with a noise level exceeding $55 \mathrm{~dB}$ are colored red. There is no road noise level below $55 \mathrm{~dB}$.

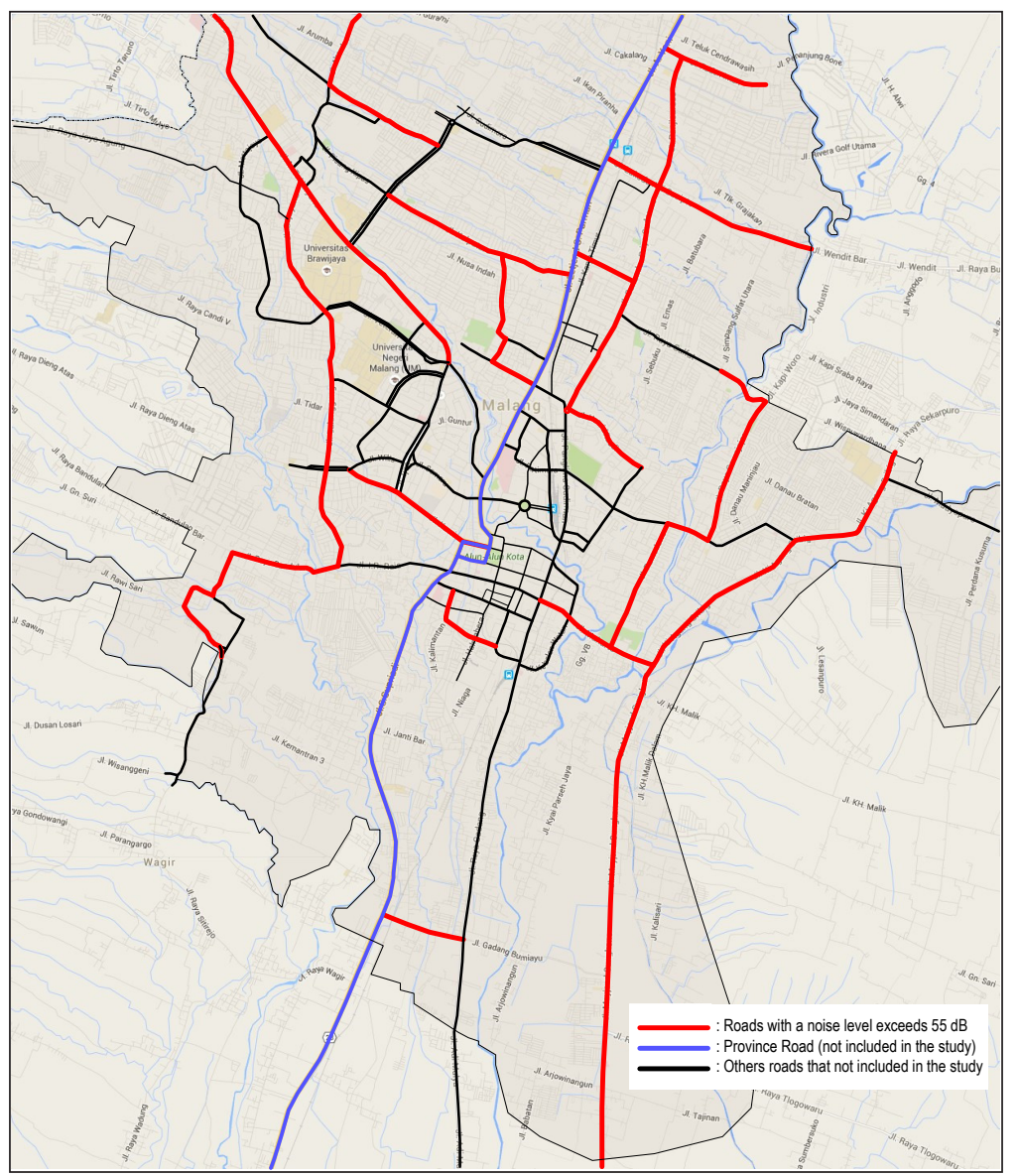

Figure 5. Traffic Noise Map in the Study Area in Malang City 
On the map image, the roads marked in blue are provincial roads. Roads that have been measured for noise levels are those that are colored red. As for the blue and black roads, no measurements were taken considering that there are almost no residential areas around them, only business premises. The map can be seen in Figure 5.

\section{DISCUSSION}

In the road sections that were the focus of the study, it was found that most of the distance from the house to the main road was 5.1-10 meters (82.58\%), while those greater than 10 meters was $12.26 \%$. The very close distance to the road, of course, the greater the noise level.

The average noise level between outside and inside the house, there is a significant difference in each function of the road section. This difference is associated with a significant decrease in noise levels in the house. However, the decrease in noise level is still in the range above the required threshold.

From the analysis of variance, it was concluded that in each group of road functions there was no difference in the average noise level both outside and inside the house. Thus it can be said that all roads in the scope of research in the city of Malang have a noise level that exceeds the required noise level standard.

The results of research in several cities such as Bandung show that the average noise level is above the national standard on the main and local roads (Pryandana, 2000). Likewise, the results of research in Manado (Balirante et al., 2020), Meulaboh (Kurnia et al., 2018), and Padang (Putra \& Lisha, 2017) show that the average noise level exceeds the specified quality standards on all major roads. and local. This is the same as what happened in the city of Malang.

If we look at the development of the number of motorized vehicles in Indonesia from 2010 to 2018 , it shows an increasing trend. From the total 76,907,127 vehicles in 2010, it increased to $146,858,760$ vehicles in 2018 . Within eight years, the number of motorized vehicles increased by $91 \%$ or $11 \%$ per year. With such an increasing trend there is also the potential for an increase in the resulting traffic noise. This happens in big cities throughout Indonesia, including in Malang.

The number of motorized vehicles which increase significantly each year has certainly led to an increase in noise levels on the road. Meanwhile, the speed of increasing road capacity in Malang City has not been able to keep up with the increase in the number of motorized vehicles. Therefore the increase in noise still exceeds the quality standard for the noise level required by the Minister of Environment Decree No. 48 of 1996. 


\section{CONCLUSIONS}

From the measurement results, that all roads targeted by the study indicate the level of noise caused by motorized traffic exceeds the noise level standard for housing and settlements ( $55 \mathrm{~dB}$ ) based on the Decree of the Minister of Environment No. 48 of 1996. The measured average noise level was $84.28 \mathrm{~dB}$, greater than $55 \mathrm{~dB}$. From the analysis of Student's t-test it was found that there was a significant difference between the noise level outside and inside the house on each road function. While from the analysis of variance, it is known that there is no difference in noise level in each road function (primary arteries, secondary arteries, primary collectors, secondary collectors, primarily local and secondary local), both outside and inside the house. This means that the existing noise level has exceeded the specified standard that is $55 \mathrm{~dB}$. It is recommended that noise levels originating from motorized vehicles on Malang city roads can be reduced to meet national requirements.

\section{ACKNOWLEDGEMENT}

This article is part of dissertation research in the Environmental Science Doctoral Program, University of Brawijaya Postgraduate Program. This research was funded by the Ministry of Research and Technology and Higher Education (Ristek Dikti) Republic of Indonesia.

\section{REFERENCES}

Alesheikh, A. A., \& Omidvari, M. (2010). Application of GIS in urban traffic noise pollution. International Journal of Occupational Hygiene, 2(2), 79-84.

Balirante, M., Lefrandt, L. I. R., \& Kumaat, M. (2020). Analisa tingkat kebisingan lalu lintas di jalan raya ditinjau dari tingkat baku mutu kebisingan yang diizinkan [Analysis of traffic noise levels on the highway in terms of permitted noise quality standards]. Jurnal Sipil Statik, 8(2), Article 2.

Djaja, I. M., \& Wulandari, R. A. (2007). Pengaruh kebisingan lalulintas jalan terhadap gangguan kesehatan psikologis anak SDN Cipinang Muara Kecamatan Jatinegara, Kota Jakarta Timur, Propinsi DKI Jakarta, 2005 [The effect of road traffic noise on psychological health problems for children at Cipinang Muara Elementary School, Jatinegara District, East Jakarta City, DKI Jakarta Province, 2005]. Makara, Kesehatan, 11(1), 32-37.

Halim, D. K. (2008). Psikologi lingkungan perkotaan [Psychology of the urban environment]. Bumi Aksara.

Ibnu, S. N. (2019). Pengaruh kebisingan lalu lintas terhadap tingkat ketergangguan individu siswa (Studi kasus: SMPN 3 kendari) [Influence of traffic noise on disturbance levels of individual students (Case study: SMPN 3 kendari)]. Jurnal Manajemen Rekayasa (Journal of Engineering Management), 1(2), Article 2.

Kurnia, M., Isya, M., \& Zaki, M. (2018). Tingkat kebisingan yang dihasilkan dari aktivitas transportasi (Studi kasus pada sebagian ruas jalan: Manek Roo, Sisingamangaraja dan Gajah Mada Meulaboh) [Noise levels resulting from transportation activities (Case studies on part of the road: Manek Roo, Sisingamangaraja and Gajah Mada Meulaboh)]. Jurnal Arsip Rekayasa Sipil dan Perencanaan, 1(2), 1-9. https://doi. org/10.24815/jarsp.v1i2.10936 
Mishra, R. K., Parida, M., \& Rangnekar, S. (2010). Evaluation and analysis of traffic noise along bus rapid transit system corridor. International Journal of Environmental Science \& Technology, 7(4), 737-750. https://doi.org/10.1007/BF03326183

Ningsih, D. H. U. (2010). Analisa optimasi jaringan jalan berdasar kepadatan lalulintas di Wilayah Semarang dengan berbantuan sistem informasi Geografi (Studi kasus Wilayah Dati II Semarang) [Analysis of road network optimization based on traffic density in the Semarang Region with the assistance of geographical information systems (Case study of Dati II Semarang Area)]. Jurnal Teknologi Informasi DINAMIK, $X V(2), 121-135$.

Pryandana, D. (2000). Penanganan kebisingan lalu lintas di jalan perkotaan: Studi kasus kota Bandung [Traffic noise handling on urban roads: A case study of the city of Bandung]. Retrieved October 24, 2020, from http://elib.unikom.ac.id/gdl.php?mod=browse\&op=read\&id=itb-s2-pl-2000-Dendi-jalan

Pudjowati, U. R., Yanuwiadi, B., Sulistiono, R., \& Suyadi, S. (2013). Effect of vegetation composition on noise and temperature in Waru-Sidoarjo Highway, East Java, Indonesia. International Journal of Conservation Science, 4(4), 459-466.

Putra, F., \& Lisha, S. Y. (2017). Tingkat kebisingan lalu lintas kendaraan di Gedung I Sekolah Tinggi Teknologi Industri (STTIND) Padang [Vehicle traffic noise level in building I of the industrial technology college (STTIND), Padang.]. Jurnal Sains dan Teknologi: Jurnal Keilmuan dan Aplikasi Teknologi Industri, 17(1), 1-7. https://doi.org/10.36275/stsp.v17i1.34

Rosidah, R. (2004). Studi kejadian hipertensi akibat bising pada wanita yang tinggal di sekitar lintasan kereta api di Kota Semarang Tahun 2004 [Study of the incidence of hypertension due to noise in women living around railway tracks in Semarang City, 2004] [MSC Thesis]. Universitas Diponegoro, Indonesia. http:// eprints.undip.ac.id/14510/1/2004MKL3810.pdf

Setiawan, I. M. D., Mahardika, I. G., \& Adhika, I. M. (2016). Tingkat kebisingan lalu lintas di lingkungan perumahan Dalung Permai Kabupaten Badung [Traffic noise level in the housing environment of Dalung Permai, Badung Regency]. ECOTROPHIC: Jurnal Ilmu Lingkungan (Journal of Environmental Science), 10(2), 81-86. https://doi.org/10.24843/EJES.2016.v10.i02.p01

Tjahjono, N., \& Nugroho, I. (2018). Tanaman hias sebagai peredam kebisingan [Ornamental plants as noise reducer]. Conference on Innovation and Application of Science and Technology (CIASTECH), 1(1), 703-710.

Wahyuni, S., Yustiani, Y. M., \& Juliandahri, A. (2019). Analisis tingkat kebisingan lalu lintas di Jalan Cihampelas dan Jalan Sukajadi Kota Bandung [Analysis of traffic noise levels on Cihampelas Street and Sukajadi Street, Bandung City]. Journal of Community Based Environmental Engineering and Management, 2(1), 9-12. https://doi.org/10.23969/jcbeem.v2i1.1451

Yadnya, I. W. P., Putra, N. A., \& Aryanta, I. W. R. (2009). Tingkat kebisingan dan tajam dengar petugas ground handling di Bandara Ngurah Rai Bali [Noise level and sharp hearing of ground handling officers at Ngurah Rai Airport, Bali]. ECOTROPHIC: Jurnal Ilmu Lingkungan (Journal of Environmental Science), 4(2). 